\title{
TINJAUAN MOTIVASI BELAJAR SISWA PADA KELUARGA YANG MENGALAMI PERCERAIAN (BROKEN HOME) DI SEKOLAH DASAR NEGERI JEMUR WONOSARI 1
}

\author{
Erika Nurkumalarini
}

Surel: Erikanur1234@gmail.com

\begin{abstract}
The purpose of this study was to determine student learning motivation in families experiencing divorce (broken home) and to find out the strategies of teachers in (broken home) at the school.From the data and data sources which doing in wonocolo, surabaya city use subject in primary school children of 4 children.Data collection techniques in this research using observation techniques, interviews, documentation until analysis technique, and in data this research method which using qualitative-descriptions. The results of this study indicate that children who have incomplete families, have broken home families, subjects still lack high motivation to learn. In addition, the strategies carried out at SDN Jemur Wonosari 1 Surabaya show that teachers teach various strategies and learning methods such as lecture methods, discussions, questions and answers, and assignments so that students are motivated to participate in learning and are active and affective so that students are not bored and are bored in learning process takes place.
\end{abstract}

Keywords: Learning, Motivation, Broken Home

\begin{abstract}
ABSTRAK
Tujuan penelitian ini untuk mengetahui terutama motivasi belajar siswa pada keluarga yang mengalami perceraian (broken home), di samping itu juga untuk mengetahui Strategi guru dalam menangani siswa yang broken home di sekolah tersebut. Sumber data yang di dapat pada penelitian ini, yang ada di Kecamatan Wonocolo Kelurahan Jemursari Kota Surabaya berjumlah 4 anak pada jenjang Sekolah Dasar. Teknik pengumpulan data pada penelitian ini menggunakan teknik observasi, wawancara, Dokumentasi. Metode penelitian yang menggunakan adalah kualitatif deskripsi. Fokus penelitian adalah masalah motivasi belajar anak-anak yang mengalami broken home. Hasil penelitian ini menunjukkan bahwa anak yang memiliki keluarga tidak lengkap (ayah atau ibu tidak ada atau kedua-duanya), kurang mempunyai motivasi belajar yang tinggi. Di samping itu strategi yang dilakukan guru-guru di SDN Jemur Wonosari 1 Surabaya menunjukkan bahwa guru mengajar dengan berbagai strategi dan metode pembelajaran yang bervariasi seperti metode ceramah, diskusi, tanya jawab, dan tugas agar siswa termotivasi mengikuti pembelajaran dan aktif serta afektif sehingga siswa tidak bosan dan jenuh dalam proses pembelajaran berlangsung.
\end{abstract}

Kata Kunci : Belajar Siswa, Motivasi, Broken Home

\section{PENDAHULUAN}

Proses Pendidikan di sekolah, kegiatan belajar merupakan kegiatan yang paling pokok. Ini berarti bahwa berhasil tidaknya pencapaian tujuan pendidikan banyak bergantung pada bagaimana proses yang dialami siswa sebagai peserta didik dalam belajar. Banyak orang belajar dengan susah payah, tetapi tidak mendapat hasil apa-apa, hanya kegagalan yang ditemukan. Penyebab seseorang tidak berhasil dalam belajar tidak lain karena belajar tidak teratur, tidak disiplin dan kurang bersemangat (aktif) tidak tahu bagaimana cara berkonsentrasi dalam belajar, mengabaikan masalah pengaturan waktu 
dalam belajar, istirahat yang tidak cukup dan kurang tidur. Keseluruhan faktor tersebut mewarnai kelangsungan belajar (Kompri 2016:277).

Secara garis besar, belajar dipengaruhi oleh dua faktor yaitu faktor internal dan faktor eksternal. Faktor internal berasal dari diri siswa itu sendiri, sedangkan faktor eksternal berasal dari luar. Menurut Hamalik dalam Kompri (2016: 231), Motivasi sangat menentukan tingkat berhasil atau gagal nya perbuatan belajar siswa. Belajar tanpa adanya motivasi kiranya akan sangat sulit untuk berhasil. Sebab, seseorang yang tidak mempunyai motivasi dalam belajar, tidak akan mungkin melakukan aktivitas belajar. Hal ini merupakan pertanda bahwa sesuatu yang akan dikerjakan itu tidak menyentuh kebutuhannya. Menurut Djamarah dalam Kompri (2016:231). Segala sesuatu yang menarik minat orang lain belum tentu menarik minat yang lain selama sesuatu itu tidak bersentuhan dengan kebutuhannya.

Secara khusus Djamarah (2011:143) mengemukakan bahwa: interaksi dari lingkungan alami dan lingkungan sosial budaya selalu terjadi dalam mengisi kehidupan siswa serta mempunyai pengaruh yang siknifikan terhadap belajar anak di sekolah. Demikian halnya dengan fasilitas belajar, siswa dapat belajar lebih baik dan menyenangkan bila satu sekolah dapat memenuhi segala kebutuhan belajar anak. Masalah yang dihadapi oleh siswa dalam belajar relative kecil, sehingga hasil belajar siswa akan lebih baik. Hal ini diperkuat oleh pendapat Ali dan Asrori (2004: 34-35), bahwa ada unsur lingkungan yang penting peranannya dalam mempengaruhi perkembangan intelek anak: 1. Keluarga. Intervensi yang paling penting oleh keluarga atau orang tua adalah memberikan pengalaman kepada anak dalam berbagai bidang kehidupan sehingga anak memiliki informasi yang banyak yang merupakan alat bagi anak untuk berpikir. 2. Sekolah. Sekolah adalah lembaga formal yang diberi tanggung jawab untuk meningkatkan perkembangan anak termasuk perkembangan berpikir anak. Dalam hal ini, guru hendaklah menyadari bahwa perkembangan intelektual anak terletak pada bagaimana guru menanganinya. Beberapa cara di antaranya adalah sebagai berikut: a. Menciptakan interaksi atau hubungan yang akrab dengan peserta didik. Dengan hubungan yang akrab sehingga secara psikologis peserta didik akan merasa aman sehingga segala masalah yang dialaminya secara bebas dapat dikonsultasi kan dengan guru mereka. b. Memberi kesempatan kepada peserta didik dalam berdialog dengan orang-orang yang ahli dan pengalaman dalam berbagai bidang ilmu pengetahuan. Hal ini sangat menunjang perkembangan intelektual anak, membawa para peserta didik ke objek-objek tertentu seperti objek yang membawa ilmu pengetahuan yang sangat menunjang perkembangan intelektual peserta didik terutama motivasi belajar nya (Kompri 2016:227228). 
Erika Nurkumalarini : Tinjauan Motivasi Belajar ...

Secara sederhana dapat dikatakan bahwa apabila anak tidak memiliki motivasi belajar, maka tidak akan terjadi kegiatan belajar sebenarnya pada diri anak tersebut. Beberapa teori motivasi belajar yang mendukung siswa untuk belajar di kelas. Sehingga siswa mencapai nilai KKM yang diharapkan. 1. Teori Kebutuhan Manusia Abraham Maslow merupakan pakar teori kebutuhan manusia yang menjelaskan konsep motivasi untuk memenuhi kebutuhan. Banyak kebutuhan dasar yang semuanya harus dipenuhi, seperti makan, rasa aman, cinta dan perawatan harga diri yang positif. Setiap anak berbeda kepentingannya di dalam memenuhi kebutuhannya. Beberapa anak ada yang lebih membutuhkan rasa afeksi dan perhatian, sementara yang lain memiliki kebutuhan psikologis dan keamanan. Banyak anak mempunyai kebutuhan yang berbeda pada waktu yang berbeda pula. 2. Teori Kepribadian Istilah motivasi umumnya digunakan untuk menggambarkan suatu dorongan kebutuhan atau keinginan untuk melakukan sesuatu. Anak akan termotivasi untuk makan manakala dia tidak makan dalam waktu tertentu. Penggunaan konsep motivasi itu ditujukan untuk menggambarkan kecenderungan umum yang mendorong ke arah tujuan tertentu. Dalam pengertian ini, motivasi sering kali dipandang sebagai karakteristik kepribadian yang relatif stabil. Banyak anak yang termotivasi untuk berprestasi,

dan banyak pula yang termotivasi untuk bersosialisasi dengan anak lain. Demikian pula anak mengekspresikan motivasinya dengan berbagai cara. Motivasi sebagai karakteristik kepribadian yang stabil merupakan konsep yang berbeda dengan motivasi untuk melakukan sesuatu dalam situasi tertentu pula. 3. Teori atribusi pada dasarnya menjelaskan empat hal tentang keberhasilan dan kegagalan dalam situasi berprestasi, yaitu: kemampuan, usaha, kesulitan tugas, dan keberuntungan. Atribusi kemampuan dan usaha berasal dari dalam individu, atribusi kesulitan tugas dan keberuntungan berasal dari luar individu. Kemampuan bersifat relatif stabil, tidak berubah, dan usaha dapat berubah. Secara sama, kesulitan tugas bersifat stabil, sementara itu keberuntungan bersifat tidak stabil dan tidak dapat di prediksikan. 4. Teori Harapan Aspek penting dalam teori harapan adalah bahwa situasi dan kondisi tertentu, probabilitas keberhasilan yang sangat tinggi akan dapat menjadi pengganggu motivasi. Teori harapan ini implikasinya penting bagi pendidikan, yaitu tugas-tugas yang diberikan kepada peserta didik hendaknya tidak terlalu mudah ataupun terlalu sukar. Demikian pula tidak memberikan saran bahwa pertanyaan yang disajikan dalam ujian memiliki tingkat kesulitan rendah atau hanya dapat dijawab oleh separuh peserta didik. Ini karena soal-soal ujian itu biasanya tidak memerlukan usaha keras, namun memerlukan pengetahuan yang telah diperoleh sebelumnya.

Secara umum keluarga adalah orang yang memiliki pertalian darah satu lainnya, yang terdiri ayah, ibu anakanaknya. Menurut Shochib (2007:17) 
keluarga dapat ditinjau dari hubungan darah dan hubungan sosial. Keluarga dalam dimensi hubungan darah merupakan suatu kesatuan sosial, yang diikat dengan hubungan darah antara satu dengan yang lainnya.

Seiring berjalannya waktu tidak semua berjalan dengan baik, banyak masalah yang dapat membuat keluarga tersebut tidak utuh dan tidak harmonis lagi. Ayah sebagai tulang punggung keluarga sibuk melakukan pekerjaan sehingga kurang perhatiannya, terhadap ibu dan anak-anaknya. Ibu juga bekerja untuk memperoleh uang serta membantu ayah. Akibat kesibukan bekerja, sering terjadi pertengkaran antara ayah dan ibu yang tidak jarang pula berakibatkan fatal yaitu perceraian. Keluarga yang tidak utuh dan tidak harmonis ini disebut keluarga broken home. Menurut Willis (2015), broken home dapat dilihat dari dua aspek yaitu keluarga yang tidak utuh yang disebabkan salah satu orang tua meninggal atau bercerai, dan anak yang orang tua tidak bercerai namun sering tidak memperlihatkan hubungan kasih sayang atau sering bertengkar.

Keharmonisan dalam keluarga akan tetap terjalin dengan baik, apabila sesama anggota keluarga saling memahami hak dan kewajibannya masing-masing. Namun, jika dalam keluarga sudah tidak ada lagi sikap saling menghargai dan menghormati, akan berakibat pada perpecahan dalam keluarga (broken home). Keluarga broken home adalah keluarga retak atau sering juga dikatakan sebagai rumah tangga berantakan. Keretakan tersebut diakibatkan oleh beberapa sebab di antaranya: rumah tangga tanpa kehadiran salah satu (ayah atau ibu) disebabkan meninggal, bercerai atau salah satu di antaranya meninggalkan keluarganya. Menurut Goode (2007:187) menyatakan broken home terjadi akibat dari perpecahan suatu unit keluarga, terputus atau retaknya struktur keluarga, sehingga fungsi dalam keluarga tidak berjalan dengan baik.

Menurut Willis (2015) broken home yaitu: 1. Keluarga itu terpecah karena strukturnya tidak utuh sebab salah satu dari kepala keluarga itu meninggal atau telah bercerai, 2. Orang tua tidak bercerai akan tetapi struktur keluarga itu tidak utuh lagi karena ayah atau ibu sering tidak di rumah, dan atau tidak memperlihatkan hubungan kasih sayang lagi.

Dalam penelitian ini yang dimaksud dengan Broken home adalah siswa yang keluarganya sudah tidak utuh akibat perceraian atau perpisahan dari kedua orang tuanya. Siswa dalam penelitian ini adalah siswa yang tinggal dengan salah satu orang tua yang bercerai dan siswa yang orang tua nya bercerai, namun tinggal dengan kerabat atau orang lain.

Walaupun, anak yang mengalami keluarga broken home juga menempuh pendidikan. Latar belakang keluarganya tentu berpengaruh pada akademik nya di sekolah. Di sekolah misalnya, akan merasa rendah diri terhadap temantemannya karena kondisi orang tuanya yang mengalami masalah. Kasus keluarga broken home yang sering kita temukan di sekolah adalah seperti malas belajar, 
penyesuaian diri kurang baik, menyendiri, agresif, membolos, dan suka menentang guru. Oleh sebab itu, perlu disadari bahwa harus memperhatikan motivasi belajar nya karena akan mempengaruhi kegiatan belajar dan baik atau buruknya perilaku anak tersebut.

Broken home berdampak negatif bagi perkembangan kepribadian anak, meskipun kita mengakui peranan lingkungan dan perkembangan individu. Broken home dapat disebabkan oleh berbagai faktor. Menurut Degum (1999:1995) dalam Agustina (2018), faktor yang menyebabkan perceraian adalah: masalah ekonomi, perbedaan antara yang besar keinginan memperoleh anak dan perbedaan prinsip hidup yang berbeda, perbedaan pemahaman dan cara mendidik anak pengaruh dukungan sosial dan pilihan lain,tetapi yang jelas semua berawal dari rasa ketidak cocok an. Tidak dapat di pungkiri bahwa terjadinya keretakan di antara kedua orangtuanya, merupakan salah satu masalah yang paling berat bagi anak, dan berdampak pada hampir semua aspek kehidupannya. Salah satu dampak negatif dari perceraian orang tua adalah kegagalan akademik yang dialami siswa di sekolah. Berdasarkan penjelasan di atas, bahwa keadaan keluarga broken home memberikan pengaruh pada perolehan motivasi belajar anak di sekolah. Motivasi belajar yang diperoleh siswa yang berasal dari keluarga broken home memiliki motivasi belajar yang rendah.

Broken home akan berdampak pada psikologi anak, anak akan sulit bergaul, gangguan mental, dan benci pada orang tuanya. Hal tersebut menjadikan anak semakin jauh dengan lingkungannya. Ketika anak mengalami broken home mereka lebih cenderung merasa tidak percaya diri. Anak-anak tersebut lebih suka menyendiri, anak broken home memiliki sikap di luar batas dan sulit dikendalikan. Bahkan mereka bersikap seolah-olah mengalami gangguan mental. Anak broken home merasa belum bisa mengerti dan menerima apa yang terjadi pada dirinya. Sehingga anak broken home menganggap semua permasalahan yang terjadi adalah kesalahan ayah dan ibunya. Solusi nya anak lebih di perhatikan jika anak tersebut mendapat masalah, keluarga selalu menjadi figur sebagai penasihat yang dapat memberikan solusi kepada anak yang mengalami broken home dan selalu memonitoring setiap perilaku anak di rumah, di sekolah, atau pun di lingkungan sekitar supaya anak tersebut merasa memiliki keluarga yang memperhatikannya.

\section{METODE PENELITIAN}

Penelitian menggunakan pendekatan kualitatif dikriptif. Menurut Moleong dalam Zainiyah (2017:37), penelitian menggunakan pendekatan kualitatif deskriptif, yaitu penelitian yang berusaha mendeskripsikan suatu gejala, peristiwa atau kejadian yang terjadi pada saat sekarang. Sedangkan penelitian kualitatif adalah penelitian yang bermaksud untuk memahami fenomena tentang apa yang dialami oleh subjek penelitian, misalnya 
perilaku, persepsi, motivasi, tindakan, dll. Secara holistik dengan cara deskripsi dalam bentuk katakata dan bahasa, pada suatu konteks khusus yang alamiah dan dengan memanfaatkan berbagai metode alamiah.

Dengan demikian, penelitian ini bertujuan untuk menjabarkan segala sesuatu yang berkaitan dengan seluruh kegiatan atau keadaan, ataupun kegiatan yang ada pada siswa keluarga broken home, terutama motivasi siswa

\section{HASIL PENELITIAN DAN PEMBAHASAN}

Dalam penelitian ini motivasi belajar siswa yang orang tuanya mengalami perceraian. Kasus dalam penelitian ini berfokus pada anak masih sekolah dan orang tuanya mengalami perceraian. Subjek meskipun berlatar belakang broken home, namun subjek masih memiliki motivasi belajar, kadang kala motivasi belajar subjek sempat menurun, hal ini dikarenakan dengan adanya keinginan dari subjek yang tidak terpenuhi. Menurut Uno, (2007 :39) mengatakan bahwa motivasi yang disebabkan oleh keinginan untuk menerima ganjaran atau menghindari hukuman, motivasi tersebut yang terbentuk dari faktorfaktor eksternal.

Dalam meningkatkan motivasi siswa di SDN Jemur Wonosari 1 Surabaya, guru menggunakan strategi belajar dirancang untuk mengoptimalkan tujuan belajar. guru dalam hal ini berfungsi sebagai sarana dalam peningkatan motivasi belajar siswa, strategi yang digunakan guru untuk meningkatkan motivasi belajar di SDN Jemur Wonosari 1 Surabaya menggunakan berbagai macam metode, di mana guru di tuntut memiliki kemampuan mengembangkan metodemetode pembelajaran dalam meningkatkan motivasi belajar siswa

Ada banyak sekali metode yang dapat digunakan dalam proses pembelajaran, pada dasarnya tujuan dari penggunaan metode pembelajaran adalah untuk memperoleh kesuksesan atau keberhasilan dalam mencapai tujuan pembelajaran. Dalam menyampaikan materi pembelajaran guru kelas di SDN Jemur Wonosari 1 Surabaya menggunakan metode yang berbedabeda, sesuai materi dengan materi pembelajaran yang akan disampaikan.

Berdasarkan hasil wawancara dengan kepala sekolah mengatakan bahwa: "Menurut saya strategi pembelajaran dalam mengatasi rendahnya motivasi belajar siswa yang orang tuanya mengalami broken home dengan strategi pembelajaran yang bergantung pada guru kelas nya masing-masing, karena guru kelas yang mengetahui bagaimana sikap anak yang orang tuanya mengalami broken home tersebut. Selain itu setiap siswa memiliki tipe belajar yang berbedabeda. Terdapat siswa yang lebih mudah menerima pembelajaran dengan metode ceramah, ada juga siswa yang mengerti jika siswa tersebut bekerja sama dengan teman nya dan ada juga siswa yang menerima pelajaran dengan cara bekerja sama dengan kelompok nya. Terkadang perbedaan siswa yang seperti inilah yang 
belum bisa kami kenali dengan yang menyebabkan sulitnya kami untuk menentukan strategi dan metode yang tepat." (KS 10 Mei 2020)

\section{Pembahasan}

Dalam proses perkembangan yang serba sulit dan masa-masa membingungkan dirinya, subjek membutuhkan pengertian dan batuan dari orang yang dicintai dan dekat dengan nya terutama orang tua atau keluarganya. Seperti yang telah di sebutkan di atas bahwa fungsi keluarga adalah memberi pengayoman sehingga menjamin rasa aman maka subjek sungguh sungguh membutuhkan realisasi fungsi keluarga. Sebab jika seseorang kehilangan pegangan yang memadai dan pedoman hidupnya. Biasanya diawali oleh konflik- konflik internal, perasaan mudah tersinggung, cita-cita dan kemauan yang tinggi tetapi, subjek sulit untuk mengerjakan nya sehingga membuat subjek frustasi, masalah keluarga yang mengalami broken home bukan menjadi masalah baru tetapi merupakan masalah yang utama dari akar-akar kehidupan seorang anak. Keluarga merupakan dunia keakraban dan diikat oleh tali batin sehingga menjadi bagian yang vital dari kehidupannya.

Prestasi belajar dari ke empat subjek setelah orang tuanya mengalami perceraian cenderung mengalami penurunan dan diantara ke empat subjek, akan tetapi subjek ke dua dan ke tiga dengan dua subjek lain sebab subjek ke dua dan ke tiga lumayan baik, walaupun di subjek kedua masih naik turun dalam prestasi belajar nya. Setelah orang tuanya mengalami perceraian hubungan subjek dengan ayahnya subjek pertama masih sering bertemu dengan ayah nya, walaupun hanya dua minggu sekali, tetapi ke tiga subjek lainnya sama-sama semakin menjauh mengenai kedekatan dan relasi dengan sang ayah. Kedekatan subjek dengan ibunya subjek pertama dan ke dua dapat disimpulkan bahwa subjek kedekatan nya baik dan setiap hari selalu komunikasi tetapi pada subjek ke tiga hubungan subjek dengan ibunya baik, walaupun komunikasi hanya lewat telepon atau WA saja. Dan sedangkan hubungan subjek ke empat, subjek semakin jarang untuk bertemu dengan ibunya.

Sifat dari ke empat subjek berbedabeda satu dengan yang lainnya namun terdapat sedikit persamaan sikap dan perilaku. pada subjek pertama subjek cenderung diam, dan tidak mudah bergaul. subjek ke dua dan ke tiga memiliki sikap dan perilaku yang sama yaitu ramah, dan mudah bergaul dengan teman-temannya sedangkan pada subjek keempat memiliki sikap dan perilaku cenderung bandel, ramah dan mudah bergaul.

Kemauan akan membuat subjek merasa terdorong untuk melakukan kegiatan belajar, tetapi jika subjek tersebut tidak memiliki kemauan akan sulit untuk merealisasikan diri dalam belajar nya. Karena motivasi adalah salah satu faktor yang mempengaruhi keefektifan dalam mengambil sebuah keputusan 
Dampak keluarga yang broken home berpengaruh pada prestasi dan motivasi belajar siswa, di sisi lain subjek menganggap belajar nya siasia. Sebab tidak ada orang tua yang menanyakan bagaimana hasil dari prestasinya sehingga anak cenderung acuh tak acuh terhadap belajar nya. Sesuai dengan pernyataan Moreover, Ayodele (2007) bahwa lingkungan di mana seorang anak menemukan dirinya juga akan berpengaruh dalam menentukan kemampuan belajar dan akhirnya kinerja akademik di sekolah

Hampir semua keluarga yang berlatar belakang broken home memiliki permasalahan yang dihadapi, sehingga menimbulkan perceraian, hal ini dibuktikan kepada keluarga ke empat subjek. Permasalahan yang dihadapi dari ke empat subjek menyangkut perekonomian keluarga, berbeda pendapat dari ke dua belah pihak keluarga. subjek pertama tidak mengetahui permasalahan kedua orang tuanya, tetapi subjek ke dua, ke tiga dan ke empat mengetahui dan menerima keadaannya bahwa orang tuanya mengalami perceraian. Kadang kala subjek mengalami kekecewaan ketika teringat bahwa orang tua nya bercerai, namun masing-masing subjek memiliki cara yang berbeda untuk menghilangkan rasa kekecewaan tersebut.

Dari ke empat subjek dapat disimpulkan bahwa keluarga berlatar belakang broken home cenderung berpengaruh pada motivasi belajar pada anak seperti : (1) anak cenderung malas, (2) anak mau belajar jika disuruh, (3) anak belajar karena ada tugas saja, (4) anak belajar karena menginginkan sesuatu. Menurut Sardiman, (2012:90-91) motivasi belajar dari ke empat subjek tersebut termasuk motivasi ekstrisik yang hanya mendapat dorongan belajar dari luar. Oleh karena itu motivasi ekstrisik dapat juga dikatakan sebagai bentuk motivasi yang di dalamnya aktivitas belajar dimulai dan diteruskan berdasarkan dorongan dari luar yang tidak secara mutlak berkaitan dengan aktivitas belajar. Perlu ditegaskan, bukan berarti motivasi ekstrisik ini tidak baik atau tidak penting dalam kegiatan belajar. Sebab kemungkinan besar keadaan siswa itu perlu mendapat dorongan.

Strategi adalah cara atau siasat yang digunakan untuk mencapai tujuan yang telah ditetapkan. Strategi yang digunakan oleh guru sangat menentukan keberhasilan dari suatu pendidikan. Pemilihan strategi yang sesuai dengan materi yang digunakan agar memudahkan siswa dalam memahami suatu materi pelajaran. Dibutuhkan strategi yang tepat dalam penyampaiannya, karena setiap siswa berbeda-beda cara belajar nya dan memahami setiap materi pembelajaran dari guru.

\section{SIMPULAN}

Maka peneliti menyimpulkan sebagai berikut:

- Motivasi belajar siswa yang mengalami broken home, tidak memiliki motivasi dari dirinya sendiri tetapi muncul bila 
Erika Nurkumalarini : Tinjauan Motivasi Belajar ...

ada terdorong oleh faktor dari luar dirinya.

- Meningkatkan motivasi subjek oleh sekolah sudah dilakukan dengan beberapa cara.

\section{DAFTAR RUJUKAN}

Abidin, Yunus. 2012. Desain Sistem Pembelajaran dalam Konteks Kurikulum 2013. Bandung: Refika Aditama.

Ambarsari, L. ; H. 2011. Pendidikan Dasar. Pendidikan Dasar, 2(Penilaian), 2-6.

Anggito, A., \& Setiawan, J. 2018. M. penelitian kualitatif. C. J. (Jejak P. (n.d.). anggito.pdf.

BSNP. 2006. Standar Isi Sekolah Dasar/Madrasah Ibtidaiyah. Jakarta : Depdikbud.

Mulyatiningsih, Endang. 2014. Metode Penelitian Terapan Bidang Pendidikan. Yogyakarta: Alfabeta.

Munandar, Utami. 2002. Kreativitas dan Keterbakatan. Jakarta: Gramedia Pustaka Media.

Uno, Hamzah. 2011. Perencanaan Pembelajaran. Jakarta: Bumi Aksara.

Slavin, Robert E.. 2010. Cooperative Learning Teori, Riset dan Praktik. Bandung: Nusa Media.

Taniredja, Tukiran. 2012. Model-Model Pembelajaran Inovatif. Bandung: Alfabeta. 